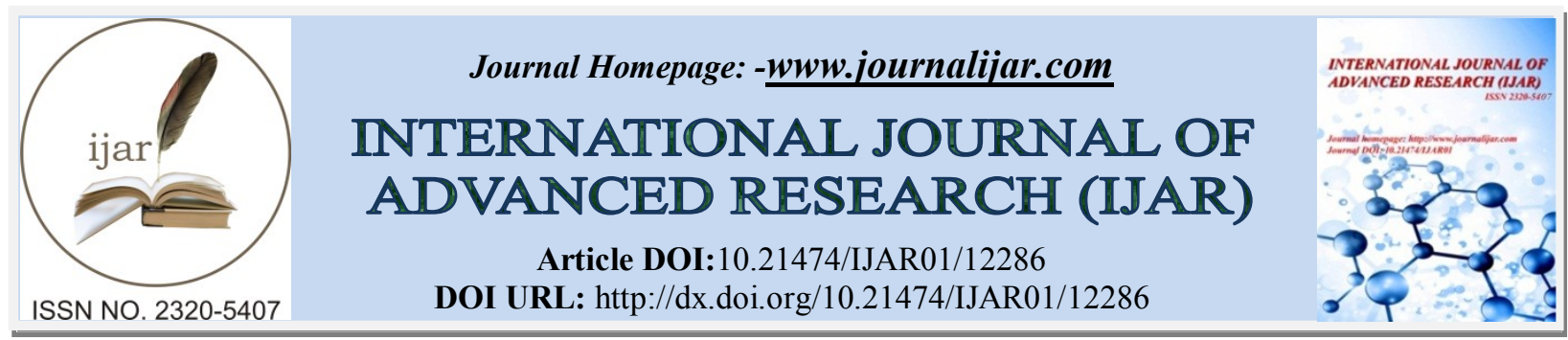

RESEARCH ARTICLE

\title{
DOES K-DIFORMATE SUPPLEMENTATION IMPROVES GROWTH AND DIET STAIBLITY OF JUVENILE WHITE SHRIMP(LITOPENAEUS VANNAMEI)?
}

\section{Mouhamadou Amadou Ly ${ }^{1,2}$, Ann-Chung Cheng ${ }^{1}$, Wai-Leong Cheah ${ }^{2}$, Cheikh Tidiane $\mathrm{Ba}^{3}$ and Chyng-Hwa Liou $^{2}$}

1. Gaston Berger University, Department of Aquaculture.

2. National Taiwan Ocean University, Department of Aquaculture.

3. Cheikh Anta Diop University, Faculty of Science.

\section{Manuscript Info}

Manuscript History

Received: 05 November 2020

Final Accepted: 10 December 2020

Published: January 2021

Key words:-

Aquaculture, Feed Additive, Growth

\begin{abstract}
A study was conducted to investigate the effects of potassium diformate (K-diformate) supplementation in two protein levels on growth, food conversion and survival in juvenile white shrimp, litoppenaeusvannamei.Two dietary protein levels, $41 \%$ dietary protein(CP41) and $37 \%$ dietary protein(CP37) was formulated and supplemented of graded K-diformate levels $0 \%, 0.1 \%, 0.2 \%, 0.4 \%$, $0.8 \%, 1.4 \%$ and $2.0 \%$.Post larvae white shrimp (Litopenaeusvannamei) of initial mean weight $0.82 \pm 0.08 \mathrm{~g}$ were randomly stocked in 45 aquarium tanks with a working volume of $50 \mathrm{~L}(60 \times 40 \times 30 \mathrm{~cm})$ at a stocking density of 10 shrimps per aquarium. The result of this study did not show significant difference in percentage weight gain and survival rate among shrimps fed CP41 and CP37 with graded Kdiformate supplemented diet. No K-diformate dose response was observed at the end of the study. The results of present study proof that $\mathrm{K}$-diformate supplemented diet do not affect water $\mathrm{pH}$ and feeding diet stability in water.
\end{abstract}

Copy Right, IJAR, 2021,. All rights reserved.

\section{Introduction:-}

Potassium diformate(KDF) known as K-diformateis a salt obtained by a specific technologyof neutralizing Kdiformatec acid with potassium hydroxideand stabilizing its carboxylic anion under pressure (Mrozet al., 2002). Potassium diformate is generally appeared in the nature and digestive tract of pigs which readily utilized by terrestrial animal. KDF act as a antimicrobial function which reduced the general bacterial population in the gut, especially harmful bacteria such as E. coli and Salmonella, and promoted a more favorable microflora in the gut(Hebeleret al., 2000). Moreover, KDF improved growth performance of piglets by an average of $11 \%$ (Øverlandet al., 2000), which have a similar effect commonly obtained by antibiotic growth promoters. Plenty of researcher in Europe showed good evidence on pig's growth performance as a growth promoter but the study on aquatic animal is still absence.

The culture of white shrimp(Litopenaeusvannamei) in Asia have a higher success than the tiger shrimp(Penaeusmonodon) recent years due to a higher stress tolerance of white shrimp. Consequently, white shrimp became the main cultured species in this past 2 years. In year 2003, the production of white shrimp in Mainland China reached 500,000 tons/year, which is the highest production in the world. 
The optimum level of dietary protein for white shrimp was determined to be $36 \%$ by Smith et al. (1985) with three different sizes of white shrimp (4.0, 9.8 and 20.8g and later revised by Lee and Lee (2018) in their study they reported the optimal dietary level of crude protein to be $34.5,35.6$, and $32.2 \%$ for small, medium,and large-sized white shrimps. In addition, Xia et al. (2010) reported that a dietary protein level of around $43 \%$ could be optimum for the rearing of L.vannamei in a high-density culture system in the absence of natural productivity

The market of commercial shrimp diet can be divided to two different protein levels, a high price product with $41 \%$ dietary protein and low price product with $37 \%$ dietary protein. The low price shrimp diet contained a higher proportion of plant protein compared to the high price products. Most of the growth promoter in terrestrial animals study has a similar effect on aquatic animals. As a result of differences between shrimp and terrestrial animal in nutrients requirement, shrimp diets were formulated to contain a higher proportion of aquatic animal by-product but terrestrial animal diets contained a higher proportion of plant protein. Most of the KDF study in terrestrial animal shows positive effects on growth performance. Hence, two protein levels of shrimp diet were designed to examine the effect on growth of white shrimp with graded K-diformate supplementation.

\section{Materials and Methods:}

\section{Experimental site and design:}

The study was conducted at the Department of Aquaculture, National Taiwan Ocean University. Post larvaewhite shrimp (Litopenaeusvannamei) of initial mean weight $0.82 \pm 0.08 \mathrm{~g}$ were randomly stocked in 45 aquarium tanks with a working volume of $50 \mathrm{~L}(60 \times 40 \times 30 \mathrm{~cm})$ at a stocking density of 10 shrimps per aquarium. Shrimps were acclimated to adapt the experimental conditions through feeding commercial feed for 5 days. The study was conducted with 3 replicate in each treatment for 80 days. Culture shrimps exposed to 18:6 hrs light/dark and received 4 meals a day $(0630,1200,1800$ and $2430 \mathrm{~h})$ during the experiment period, daily feeding rate set at $7 \%$ of shrimp body wet weight in the first meal and were adjusted in the following day to maintain a fitness growth performance according to the feed consumption of culture shrimps.

During the experiment, blue canvas were used to avoid aquarium factor, all aquarium was covered by net to avoid shrimp jump out from aquarium. Temperature maintained at $30^{\circ} \mathrm{C}$, salinity at $17^{0} \%_{00}$ and the $\mathrm{pH}$ value was monitored within the whole trial. The flowing rate of each aquarium maintained at $2 \mathrm{~L} / \mathrm{min}$ and decreased to $1 \mathrm{~L} / \mathrm{min}$ following with UV light deactivated at day $41^{\text {th }}$. Ammonia-N was detected below $0.5 \mathrm{ppm}$ in the whole trial.

\section{Experiment diet:}

The major protein source was Superior standard Chilean fish meal(El golfo fishmeal), wheat flour as binder and wheat gluten were used to adjust the protein level. Two dietary protein levels, $41 \%$ dietary protein(CP41) and $37 \%$ dietary protein(CP37) was formulated and supplemented of graded K-diformatelevels $0 \%, 0.1 \%, 0.2 \%, 0.4 \%, 0.8 \%$, $1.4 \%$ and $2.0 \%$. Procedures and storage of experimental diets were similar with those described by Baiand Kim. (1997). A commercial diet was taken as a control.

\section{Effects of K-diformate supplement on feed stability in water:}

After feed formulation, samples of different diets were randomly taken, an observations were held for 24 hours in order to know the stability of the feed in $17 \%$ water.

\section{Effects of feeding diet leaching on water $\mathrm{pH}$ :}

$5 \mathrm{~g}$ sample of feeding diets was taken randomly and put into $17^{0} \%$ water at room temperature maintained approximately at $25^{\circ} \mathrm{C} . \mathrm{pH}$ value of treatments were monitored by $\mathrm{pH}$ meter(Suntex SP-701) and recorder $(\mu \mathrm{R} 1000$ Recorder, YOKOGAWA) for 24 hours.

\section{Effects of K-diformate supplement on body colour after cooking:}

After the feeding experiment, 3 shrimps from treatments $0 \%, 0.1 \%, 0.2 \%, 1.4 \%$ of CP41 and CP 37 were randomly sampled. A photographic observation was taken after shrimp cooked in boiled water for 3 minutes

\section{Measurements/calculations and statistical methods:}

All shrimp in each aquarium were weightedat 5 interval for growth performances. The first weight was taken at day $20^{\text {th }}$, and then each 15 days during the experiment period.

The formulae used to calculate the growth parameters are provided below: 
1. feed conversion ratio FCR $(\mathrm{g} / \mathrm{g})=($ Quantity of feed distributed $(\mathrm{g}) \times$ Dry matter content of feed $) /($ final wet mass (g) - initial wet mass $(\mathrm{g}))$;

2. Percentage weight gain (WG, $\%)=100 \times($ final wet mass $(\mathrm{g})$ - initial wet mass $(\mathrm{g})) /$ initial wet mass $(\mathrm{g})$;

3. Specific growth rateSGR $\left(\mathrm{SGR}, \% \mathrm{day}^{-1}\right)=100 \times(\mathrm{Ln}$ final wet mass $(\mathrm{g})-\mathrm{Ln}$ initial wet mass $(\mathrm{g})) /$ duration in days;

4. Survival $\operatorname{rate}(\%)=100 \times$ (final amount of shrimp) $/$ (initial amount of shrimp)..

Results are presented as mean \pm SEM. Data were subjected to one-way analysis of variance (ANOVA) to test the main effect of K-diformate supplementation. Treatment effects were considered significant at 5\%; Duncan's new multiple range tests was used to compare significant difference among treatments. The survival data were transformed into a normal distribution using the arcsine square root prior to analysis of variance. All statistical analysis was carried out using the SAS/PC statistical software.

\section{Results:-}

Water quality parameters:

The water temperature ranged from 30.62 to $31.42^{\circ} \mathrm{C}$; the dissolved oxygen varied between 6.98 to $8.22 \mathrm{mg} / \mathrm{L}$, and the $\mathrm{pH}$ ranged from 8.0 to 6.50 (Fig. 1).

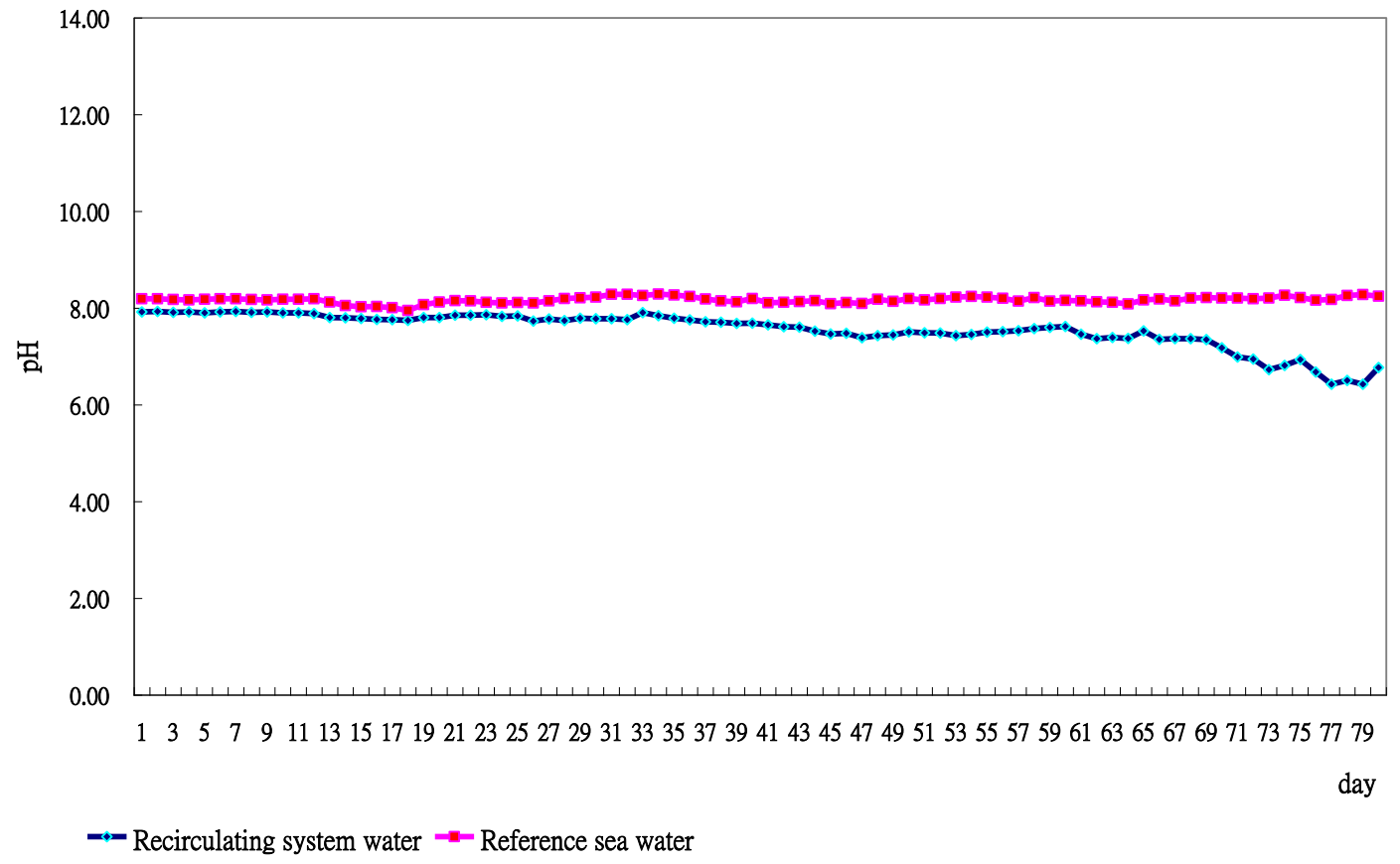

Fig. 1:- The changes of $\mathrm{pH}$ value in the recirculating system within growth trial period.

\section{Growth performance:}

There is no significant difference in percentage weight gain, SGR, FCR and survival rate in shrimps fed diet supplemented with various level of K-diformate (Fig. 2, 3, 4). 


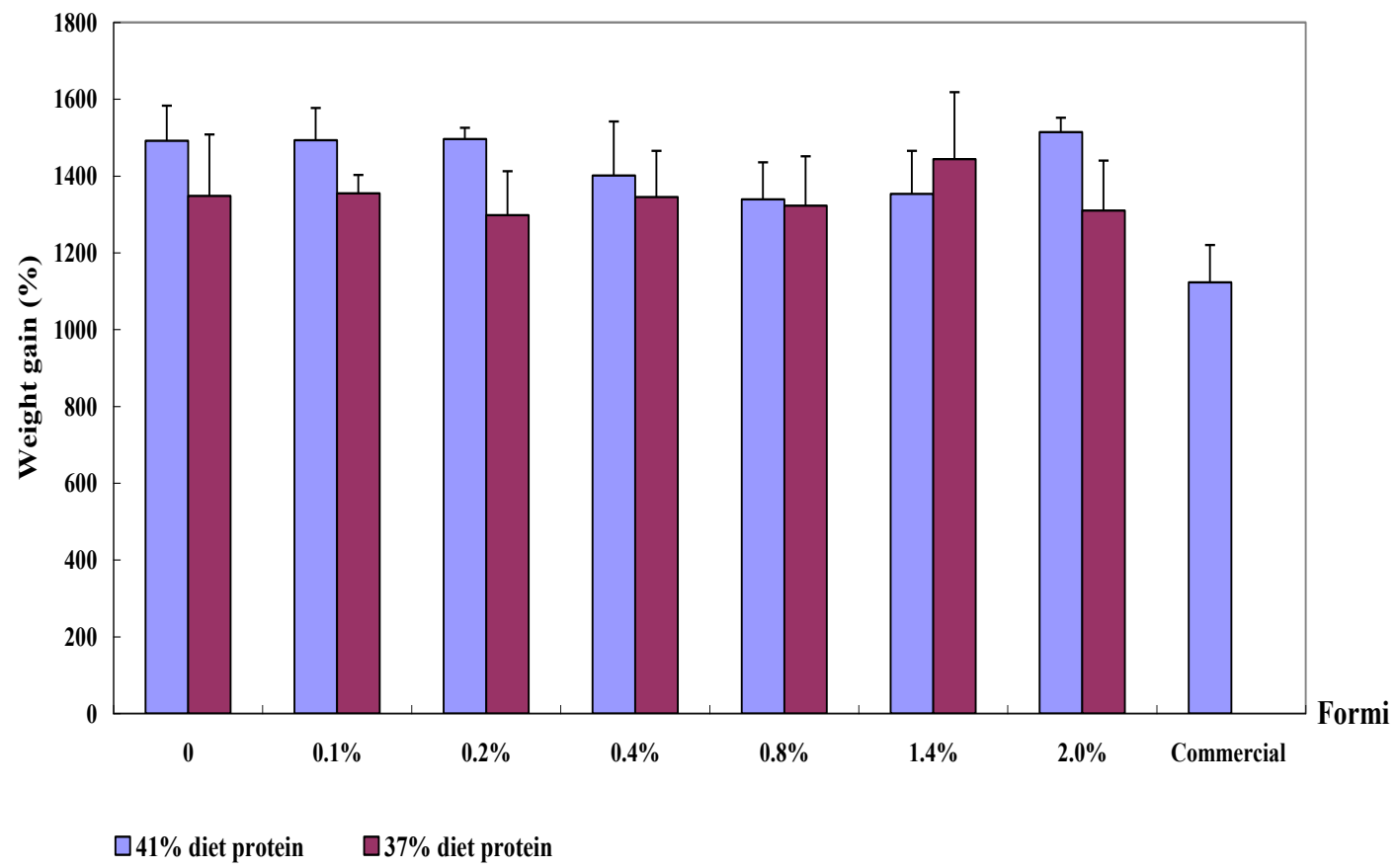

Fig. 2:- Growth performance of white shrimp, Litopenaeusvannamei, fed diets with two different protein levels, and seven graded K-diformate level for 80 days

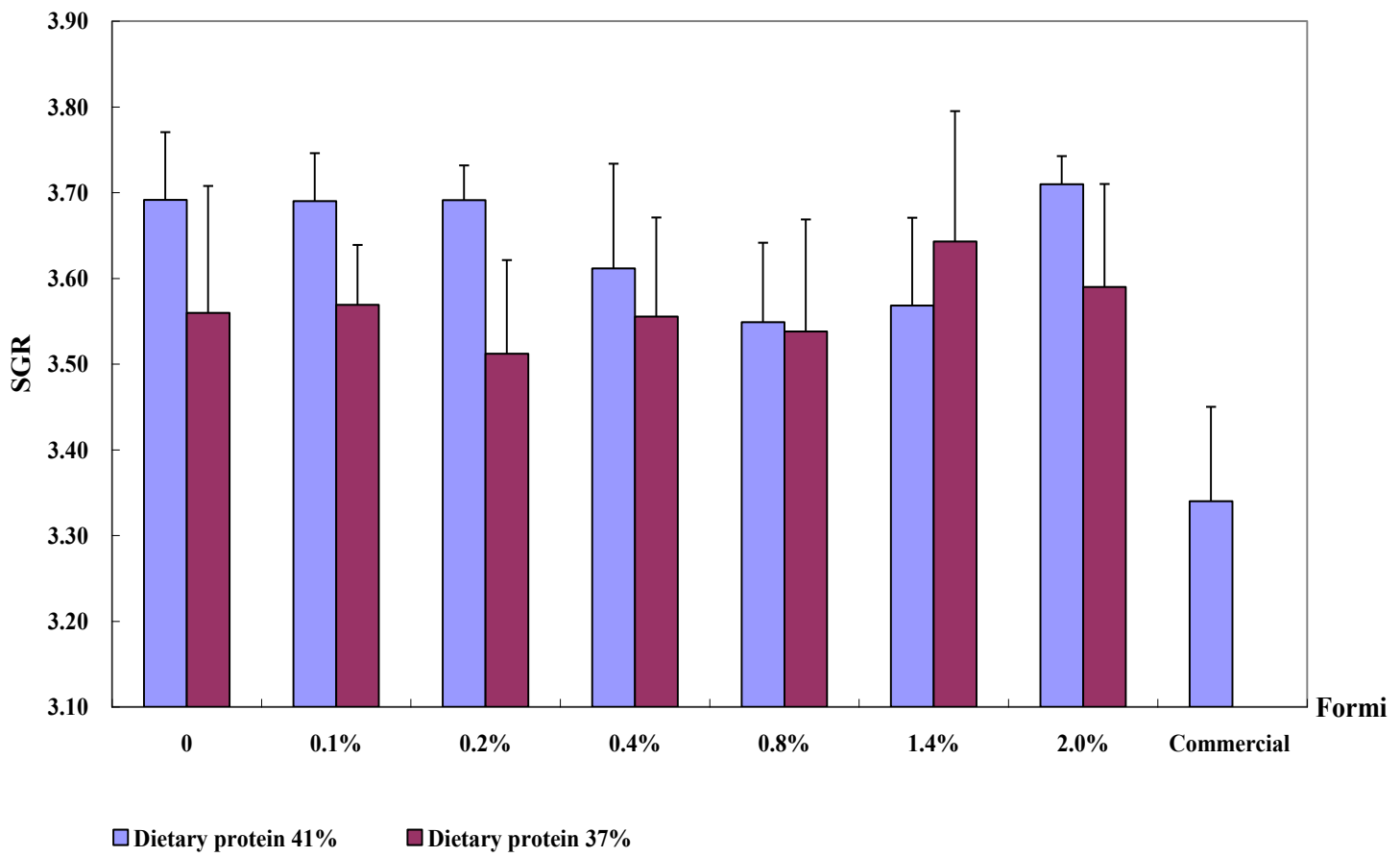

Fig. 3:- Specific growth rate of white shrimp, Litopenaeusvannamei, fed diets with two different protein level, and seven graded K-diformate level for 80 days. 


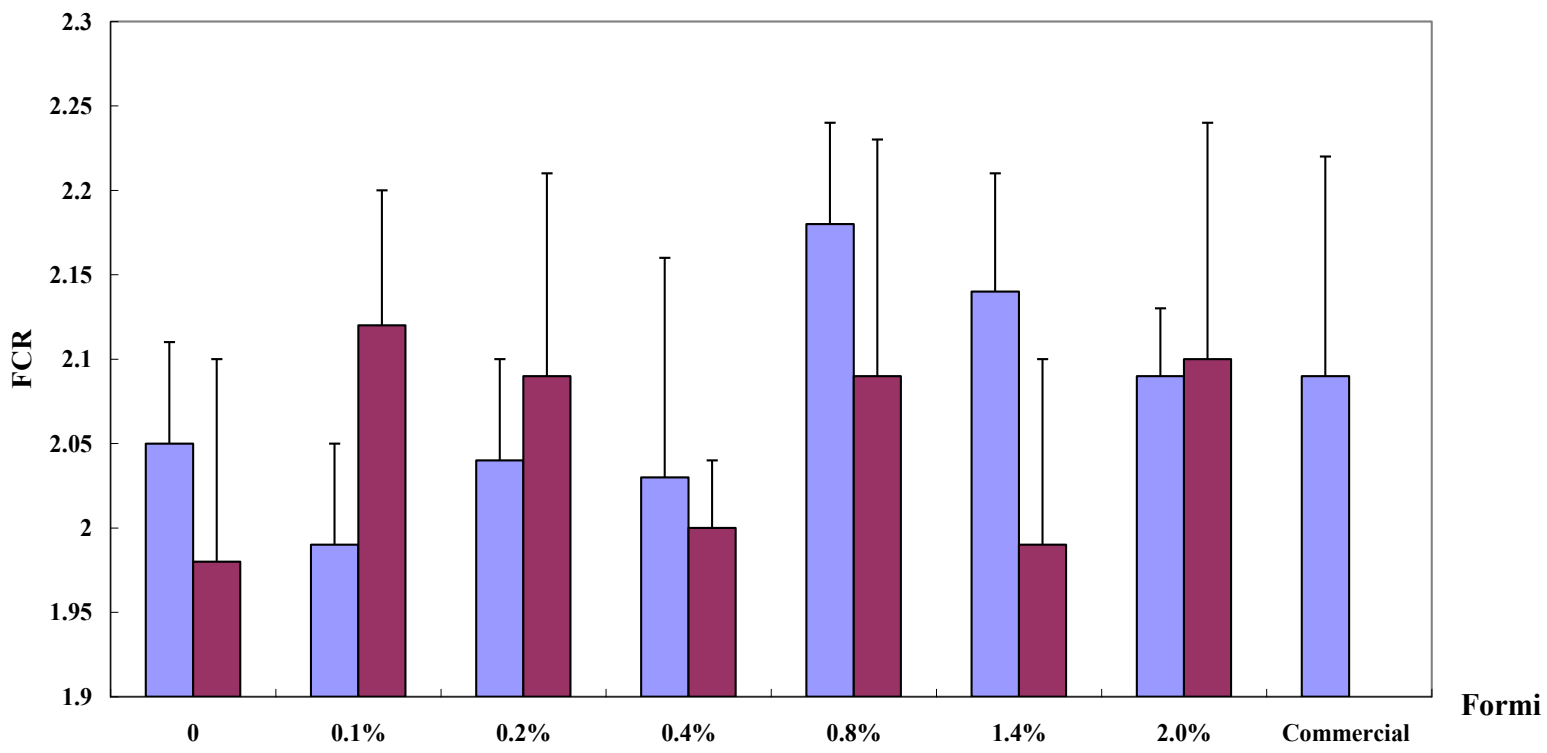

$\square 41 \%$ diet protein $\quad \square 37 \%$ diet protein

Fig. 4:- Feed conversion rate of white shrimp, Litopenaeusvannamei, fed diets with two different protein levels, and seven graded K-diformate level for 80 days.

\section{Effects of feeding diet leaching on water $\mathrm{pH}$ :}

Two protein level with $0 \%, 0.1 \%, 0.2 \%, 0.8 \%$ and $2.0 \% \mathrm{~K}$-diformate supplemented diet in $17 \%$ water was undertaken to understand the effect on water $\mathrm{pH}$. The result showed the variation of $\mathrm{pH}$ maintained at 5.0-6.5. All diets $\mathrm{pH}$ value decreased 0.5 in half an hour, $\mathrm{pH}$ value of $0.0,0.2$ and $0.8 \% \mathrm{~K}$-diformate supplemented diet maintained at $\mathrm{pH} 6.0$ after 11 hours. 2.0\% K-diformate supplemented diet reached pH 5.5-6.0 after 11 hours. All diets dropped to $\mathrm{pH} 5.5$ after 15 hours and maintained at $\mathrm{pH} 5.5$ after 19 hours. The result revealed that supplementation of K-diformate did not affect water $\mathrm{pH}$ (Fig.5).

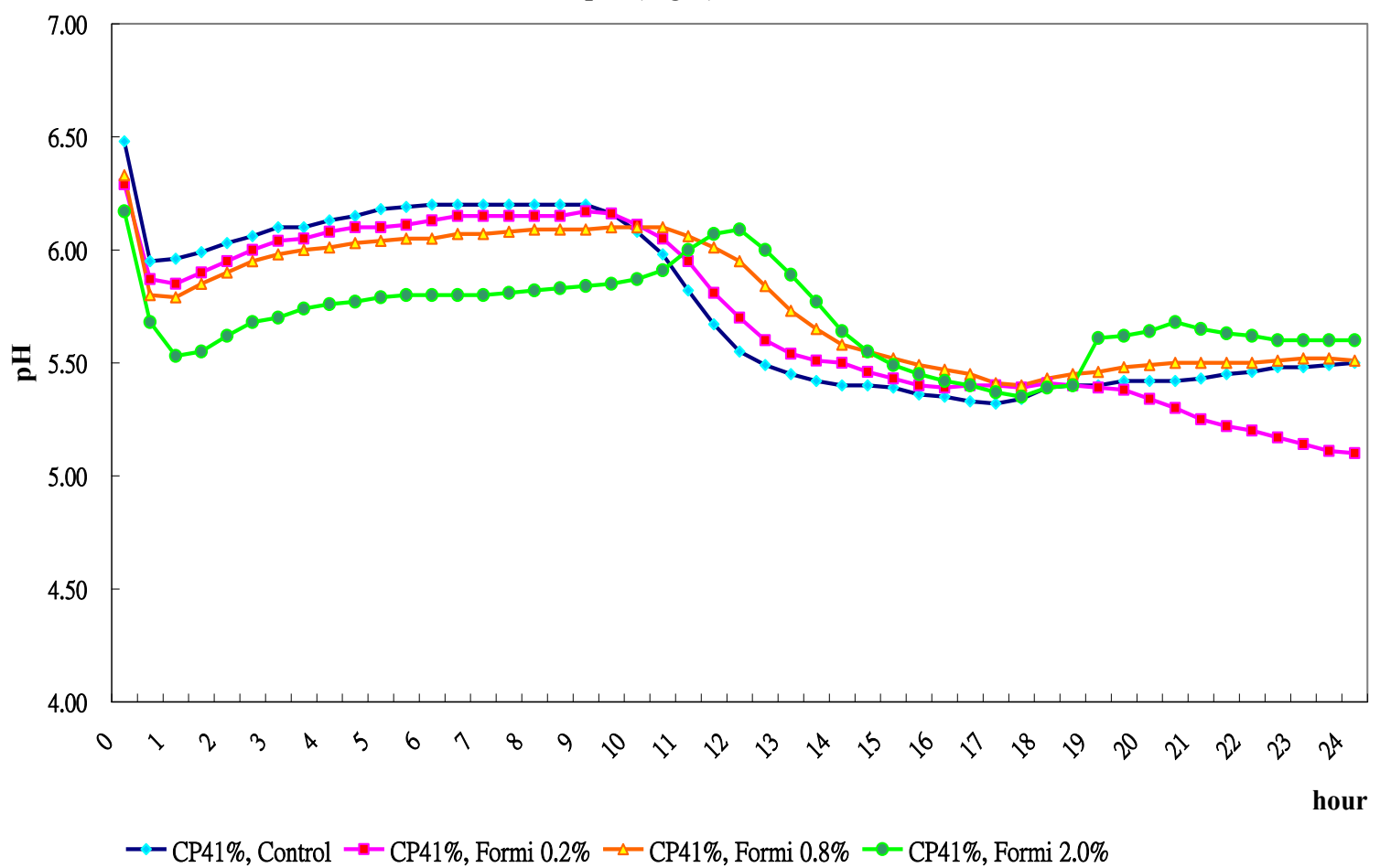

Fig. 5:- $\mathrm{pH}$ variation of $100 \mathrm{ml}$ water with $5 \mathrm{~g}$ feed diet in 24 hours. 


\section{Effects of K-diformate supplement on feed stability in water:}

Two protein level with $0 \%, 0.1 \%, 0.2 \%, 0.8 \%$ and $2.0 \%$ K-diformate supplemented diet was use to investigate the feed diet stability in water. The result revealed that the water stability of K-diformate supplemented diet, control and commercial diet are similar, K-diformate supplementation in diet do not affect feed diet stability in water (Fig. 6).

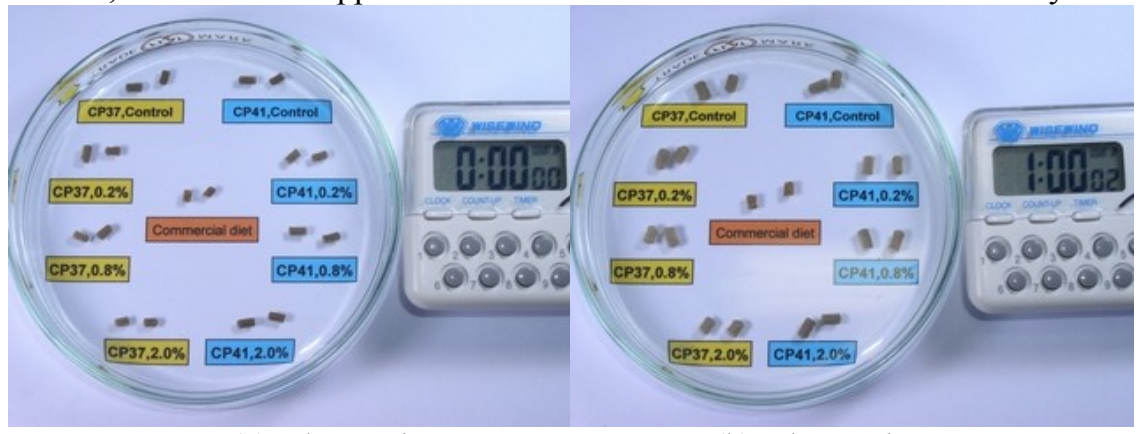

(a) 0 h 00 min

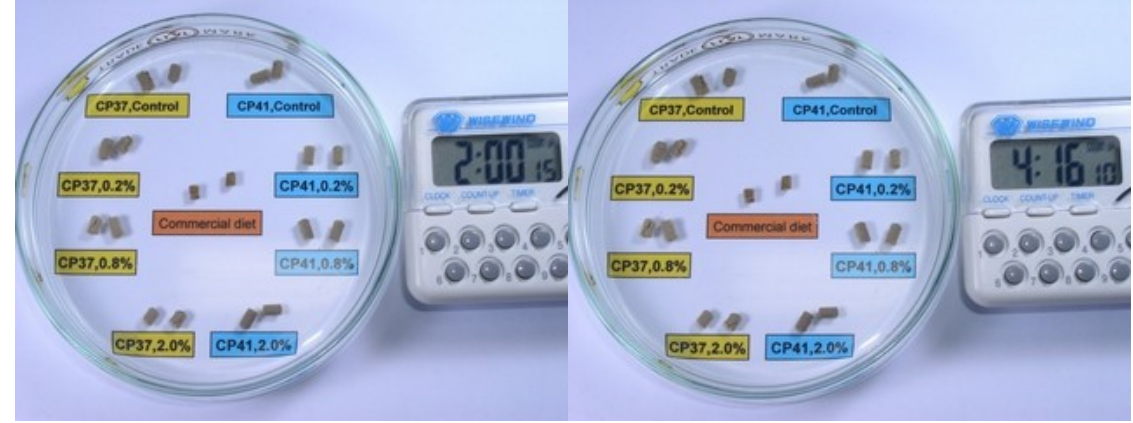

(c) 2 h $00 \mathrm{~min}$

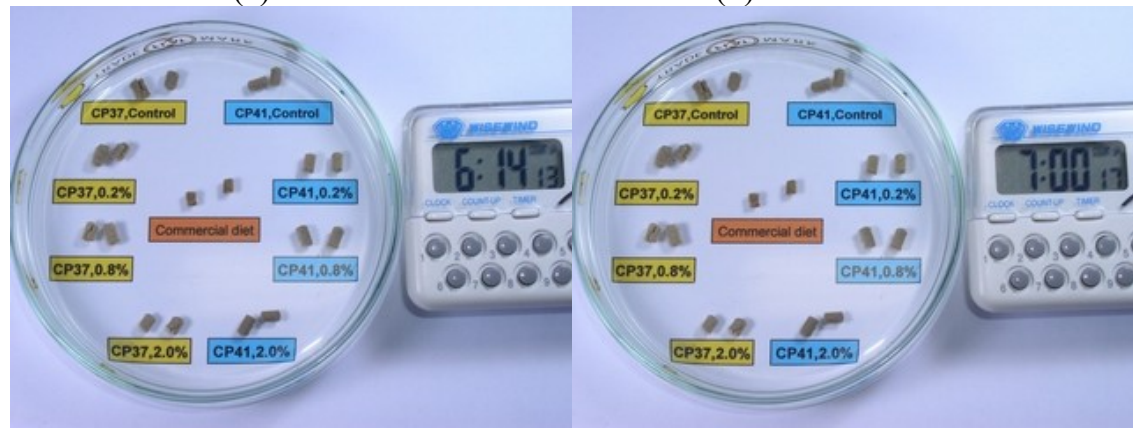

(e) 6 h $00 \mathrm{~min}$

(f) $7 \mathrm{~h} 00 \mathrm{~min}$

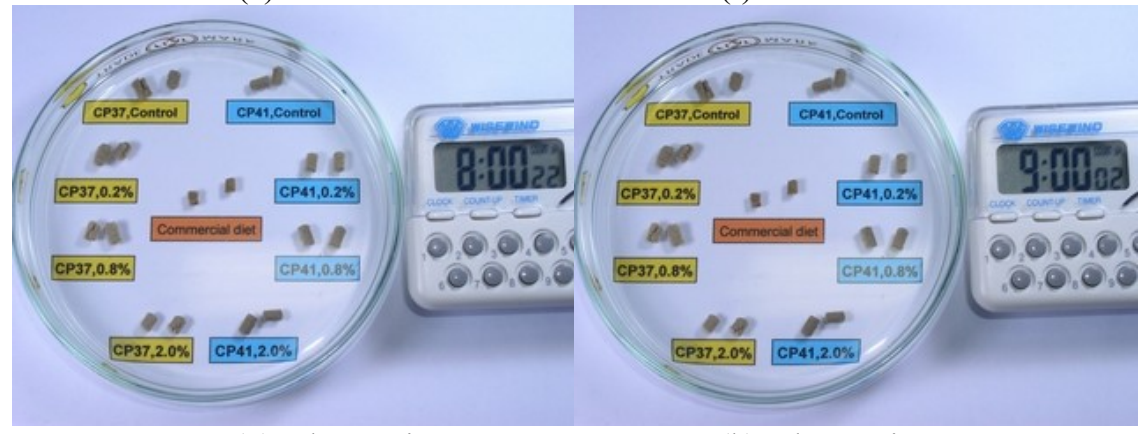

(g) $8 \mathrm{~h} 00 \mathrm{~min}$

(h) $9 \mathrm{~h} 00 \mathrm{~min}$ 


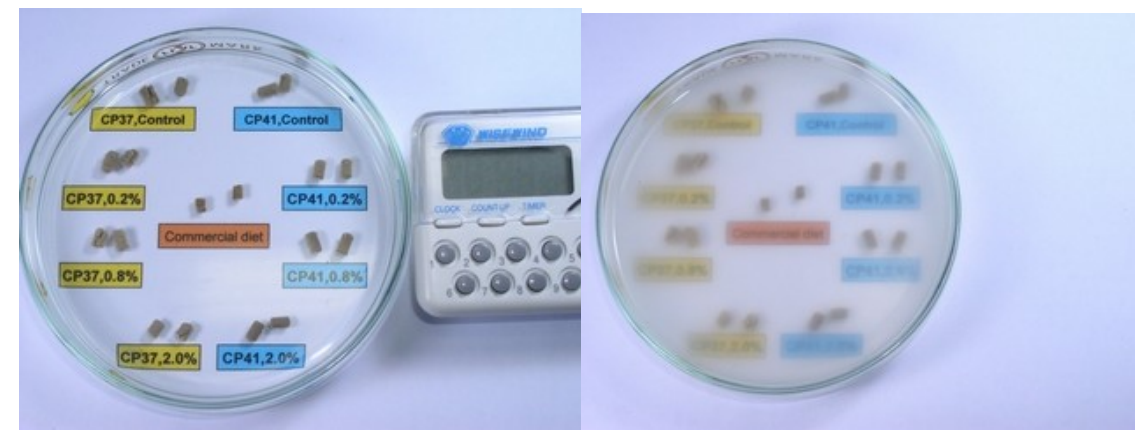

(i) $10 \mathrm{~h} 00 \mathrm{~min}$

(j) $24 \mathrm{~h} 00 \mathrm{~min}$

Fig. 6:- Water stability of test diets in 24 hours.

\section{Effects of K-diformate supplement on body colour after cooking:}

3 shrimps fed CP41 diet and 3 shrimps fed CP37 with $0,0.1,0.2,1.4 \% \mathrm{~K}$-diformate supplemented diet and commercial diet were removed and cooked in boiled water to understand the changed of body colour. The result showed in figure 7 and 8, both body colour and deshelled body colour are deeper in shrimp fed with 0 and $0.1 \%$ of K-diformate supplemented diet compared to $0.2 \%$ and $1.4 \%$ of K-diformate supplemented diet.

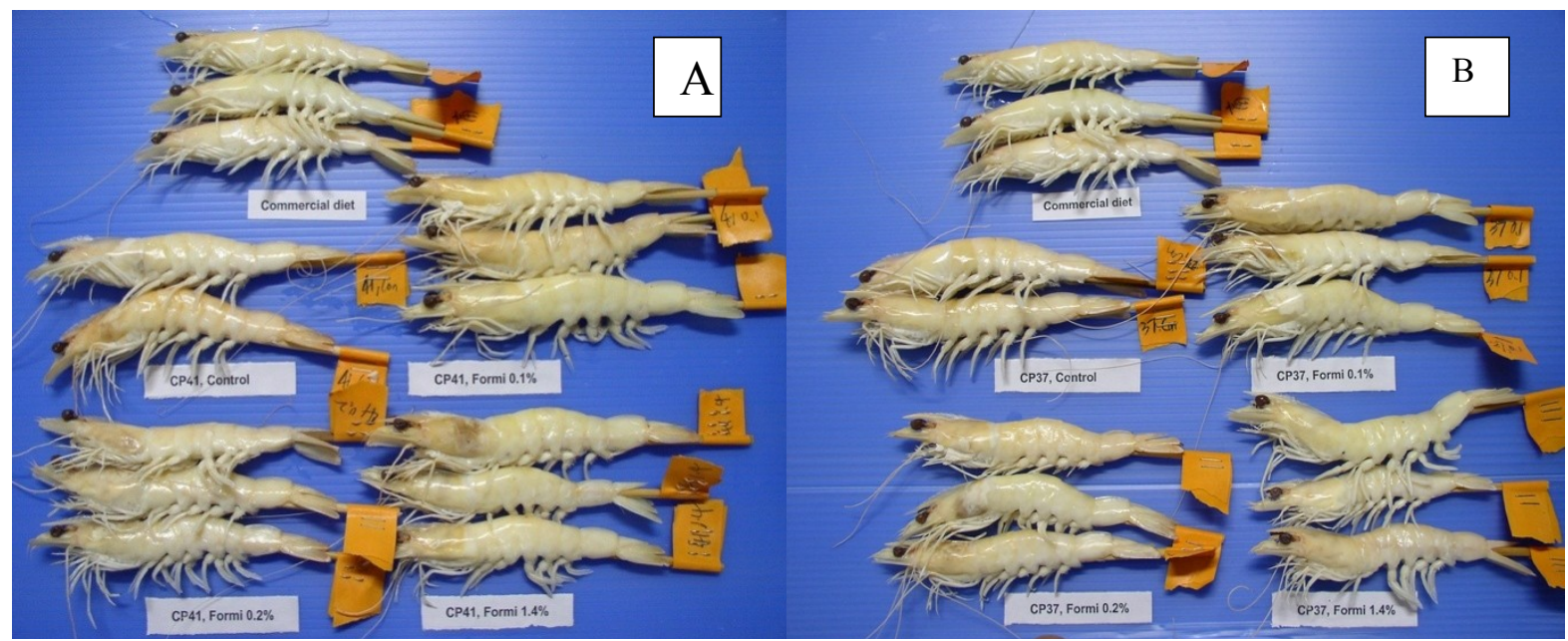

Fig. 7:- Whole body color of white shrimp fed $41 \%$ CP (A) and 37\% (B) diet with different K-diformate levels after cook for 3 minutes.

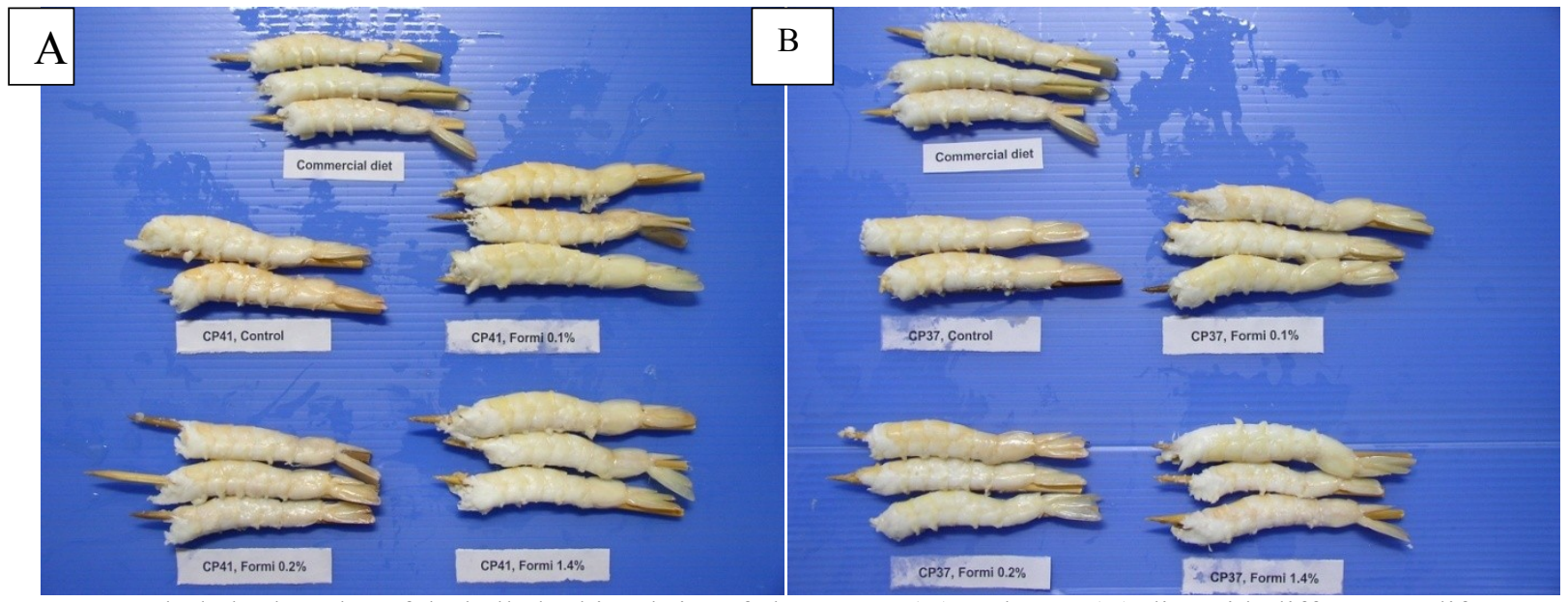

Fig. 8:-Whole body color of deshelled white shrimp fed $41 \%$ CP (A) and 37\% (B) diet with different K-diformate levels after cook for 3 minutes. 


\section{Discussions:-}

Water quality parameters:

The water quality parameters such as the water temperatures, dissolved oxygen and the $\mathrm{pH}$ values were within acceptable ranges for $L$. vannamei culture (Treece, 2000). The unionized ammonia and nitrite values observed in this study remained below the respective safety levels for shrimp culture (Ammonia and nitrites remained between 0.170.19 and 0.10-0.11 $\mathrm{mg} \mathrm{L}^{-1}$, respectively), Frías-Espericuetaet al., 1999; Lin \& Chen, 2003, Naranjo et al., 2012; Suriyaet al., 2016.

\section{Growth performance:}

Organic acids are mainly used as feed additives for improving growth performance of animals such as, pigs and poultry (Dibner and Buttin 2002; Franco et al., 2005;Lückstädt and Mellor 2011;Papatsiros and Billinis 2012);many benefit of organic acids are also reported in aquatic animals, including red hybrid tilapia (Ng et al., 2009; Koh et al., 2014), yellowtail (Sarkeretal., 2012), rohu (Baruah et al., 2007), black tiger shrimp (Ng et al., 2015), and Pacific white shrimp (Walla et al., 2012; da Silva et al., 2013;Suet al., 2014; Romano et al., 2015). Nevertheless, the results of our study shows that the growth parameters were not affected either by the proteins levels of the diet nor by the various K-diformate levels supplementation. Similar findings are reported in our previously study on the same species (Ly et al., 2019).

This could be explained bythe digestive tract of shrimp which is much shorter compared to fishes and other terrestrial animal and that feed evacuation time in digestive tract is short. The above reasons may reduce the efficiency of K-diformate to form a good microbial stage.

\section{Effects of feeding diet leaching on water $\mathrm{pH}$ :}

All diets $\mathrm{pH}$ value decreased 0.5 in half an hour, $\mathrm{pH}$ value of $0.0,0.2$ and $0.8 \% \mathrm{~K}$-diformate supplemented diet maintained at $\mathrm{pH} 6.0$ after 11 hours. 2.0\% K-diformate supplemented diet reached $\mathrm{pH}$ 5.5-6.0 after 11 hours. All diets dropped to $\mathrm{pH} 5.5$ after 15 hours and maintained at $\mathrm{pH} 5.5$ after 19 hours. The result revealed that supplementation of K-diformate did not affect water $\mathrm{pH}$.The decreasing of water renewing may cause Ammonia-N changed nitrite through nitrification in water, consequently decreased $\mathrm{pH}$ level in the water recirculation system.

\section{Effects of K-diformate supplement on feed stability in water:}

The result revealed that the water stability of K-diformate supplemented diet, control and commercial diet are similar, K-diformate supplementation in diet do not affect feed diet stability in water.The minimal disintegration of the pellet physical integrity after two hours was good, meaning that the pellet water stability was high. In addition, the high pellet water stability minimize nutrient leaching while in the water until consumed by the shrimps. Shrimps needs that the pellets to be stable in water for few hours (Tacon, 1996).

\section{Effects of K-diformate supplement on body colour after cooking:}

The reddish colour to shrimp, which has been associated with its high quality, is one of the major factors for its acceptability by consumers (Parisentiet al., 2011).The result showed in figure 9 and 11, both body colour and deshelled body colour are deeper in shrimp fed with 0 and $0.1 \%$ of K-diformate supplemented diet compared to $0.2 \%$ and $1.4 \%$ of K-diformate supplemented diet. The evidences showed K-diformate supplement might affect absorption of astaxanthin, a further study is needed to prove the above phenomena.

\section{Conclusion and Recommendations:-}

The result of this study did not showsignificant difference in percentage weight gain and survival rate among shrimps fed CP41 and CP37 with graded K-diformate supplemented diet. No K-diformatedose response was observed at the end of the study. The results of present study proof that K-diformate supplemented diet do not affect water $\mathrm{pH}$ and feeding diet stability in water. A further study is recommended with higher levels of K-diformate addition.

\section{References:-}

1. Bai SC, Kim KW. 1997. Effect of dietary animal protein sources on growth and body composition in Korean rockfish, seabastesschleglii. Aquaculture 10:77-85.

2. Dibner JJ, Buttin P.2002. Use of organic acids as a model to study the impact of gut microflora on nutrition and metabolism. J Appl Poult Res. 11:453-463. 
3. Franco LD, Fondevila M, Lobera MB, Castrillo C. 2005. Effect of combinations of organic acids in weaned pig diets on microbial species of digestive tract contents and their response on digestibility. $\mathbf{J}$ AnimPhysiolAnimNutr (Berl) ;89(3-6):88-93.

4. Frias-Espericueta, MG, Harfush-Melendez M , OsunaLo' pez JI , Pa'ez-Osuna F. 1999. Acute toxicity of Ammonia to juvenile shrimp Penaeus vannamei Boone. Bulletin of Environmental Contamination and Toxicology 62, 646-652

5. Hebeler D, Kulla S, Winkenwerder F, Kamphues J, Zentek J, Amtsberg G. 2000. Influence of a formic-acidpotassium- formate-complex on chime composition as well as on the intestinal microflora of weaned piglets . Hannover 54th Proc. Soc. Nutr. Physiol. Göttingen, Germany. March 7-9.

6. Koh CB, Romano N, Zahrah AS, Ng WK. 2014. Effects of a dietary organic acids blend and oxytetracycline on the growth, nutrient utilization and total cultivable gut microbiota of the red hybrid tilapia, Oreochromis sp., and resistance to Streptococcus agalactiae. Aquacult Res. 2014

7. Lee C, Lee KJ. 2018.Dietary protein requirements of Pacific white shrimp (Litopenaeusvannamei) in three different growth stages. Fisheries and aquatic sciences : 21-30

8. Lin Y, Chen J. 2003. Acute toxicity of nitrite on Litopenaeusvannamei (Boone) juveniles at different salinity levels. Aquaculture, 224: 193-201.

9. Lückstädt C, Mellor S. 2011. The use of organic acids in animal nutrition, with special focus on dietary potassium diformate under European and Austral-Asian conditions. Recent Adv AnimNutr Aust. 18:123-130.

10. Ly MA, Liou CH, Cheng AC. 2019. Dietary potassium diformate (Formi) supplementation on juvenile white shrimp (Litopenaeusvannamei) diets for growth and survival support. Journal of applied biosciences 134: 13722-13729

11. Mroz Z, Reese DE, Øverland, Diepen MJTM, Kogut J. 2002. The effects of potassium diformate and its molecular constituents on the apparent ileal and fecal digestibility and retention of nutrients in growingfinishing pigs. Journal of animal science 80: 681-690

12. Naranjo JMA, Voltolina D, Beltrán ER. (2012). Culture of white shrimp (LitopenaeusvannameiBoone, 1931) with zero water exchange and no food addition: an eco- friendly approach. Lat. Am. J. Aquat. Res., 40(2): 441447.

13. Ng WK, Koh CB, Sudesh K, Siti-Zahrah A. 2009. Effects of dietary organic acids on growth, nutrient digestibility and gut microflora of red hybrid tilapia, Oreochromis sp., and subsequent survival during a challenge test with Streptococcus agalactiae. Aquacult Res. 2009;40(13):1490-1500.

14. Ng WK, Koh CB, Teoh CY, Romano N. 2015. Farm-raised tiger shrimp, Penaeus monodon, fed commercial feeds with added organic acids showed enhanced nutrient utilization, immune response and resistance to Vibrio harveyi challenge. Aquaculture. 2015

15. Øverland M, Granli T, Kjos, NP, Fjetland O, Stokstad M, Steien SH. (2000). Effect of dietary formates on growth performance, carcass traits, sensory quality, intestinal microflora, and stomach alterations in growingfinishing pigs. J. Anim. Sci. 78, 1875-1884.

16. Papatsiros G, Billinis C. 2012. The prophylactic use of acidifiers as antibacterial agents in swine. In: Bobbarala V, editor. Antimicrobial agents. Croatia: InTech, Rijeka; 20-42.

17. Parisenti J, Beirao LH, Tramonte VLCG, Ourique F, Brito CCdS, Moreira. CC. 2011. Preference ranking of colour in raw and cooked shrimps. Volume 46 issue 12 Pages 2558-2561

18. Romano N, Koh CB, Ng WK. 2015. Dietary microencapsulated organic acids blend enhances growth, phosphorus utilization, immune response, hepatopancreatic integrity and resistance against Vibrio harveyi in white shrimp, Litopenaeusvannamei. Aquaculture.435:228-236.

19. Sarker MSA, Satoh S, Kamata K, Haga Y, Yamamoto Y. 2012. Supplementation effect(s) of organic acids and/or lipid to plant protein-based diets on juvenile yellowtail, SeriolaquinqueradiataTemminck Schlegel 1845, growth and nitrogen and phosphorus excretion. Aquacult Res. 43(4):538-545.

20. Silva BC, Vieira FN, Mouriño JLP, Ferreira GS, Seiffert WQ. 2013. Salts of organic acids selection by multiple characteristics for marine shrimp nutrition. Aquaculture. 2013;384-387:104-110.

21. Smith LL, Lee PG, Lawrence AL, Strawn K. 1985. Growth and digestibility of three sizes of Penaeus vannameiboone: Effects of dietary protein level and protein sources. Aquaculture 46, 85-96

22. Su X, Li X, Leng X, Tan C, Liu B, Chai X, Guo T. 2014. The improvement of growth, digestive enzyme activity and disease resistance of white shrimp by the dietary citric acid. Aquacult Int. 22:1823-1835.

23. Suriya M, Shanmugasundaram S, Mayavu P. (2016) Stocking density, Survival rate and Growth performance of Litopenaeusvannamei - (Boon, 1931) in different cultured shrimp farms. Int. J. Curr. Res. Biol. Med. 1(5): 2632 
24. Tacon AGJ. 1996. Nutritional studies in crustaceans and the problems of applying research findings to practical farming systems. Aquaculture Nutrition, 1: 165-174.

25. Treece GD. (2000). Shrimp culture. In: R.R. Stickney (ed.). Encyclopaedia of aquaculture. John Wiley \& Sons, New York, pp.798-868.

26. Walla W, Purivirojkul W, Chuchird N, Limsuwan C. 2012. Effects of activate DA on growth, survival and the total number of bacteria and Vibrio spp. in rearing of pacific white shrimp (Litopenaeusvannamei) KU Fish Res Bull. 36(2):14-22.

27. XiaS, Li Y, Wang W, Rajkumar M, Paramasivam K, Vasagam K, Wang H. 2010. Influence of dietary protein levels on growth, digestibility, digestive enzyme activity and stress tolerance in white-leg shrimp, Litopenaeusvannamei (Boone, 1931), reared in high-density tank trials. Aquaculture Research 41: 1845-1854. 